\title{
Poradenský systém
}

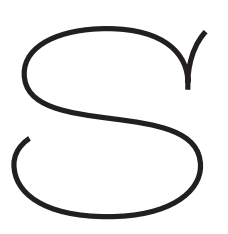

\section{pre vol'bu povolania v období socializmu na území Čiech a Slovenska ${ }^{1}$}

\section{Kristína Liberčanová ${ }^{a}$ \author{
fakulta, Katedra pedagogických štúdií
} \\ Trnavská univerzita v Trnave, Pedagogická kristina.libercanova@truni.sk}

a

Received 1 June 2020

Accepted 3 May 2021

Available online 31 December 2021

DOI 10.15240/tul/006/2021-2-001
Abstract Vocational Guidance during the Period of Socialism in the Territory of Bohemia and Slovakia

In the period of socialism, career guidance is an important policy tool in meeting government policy goals. The state systematically intervenes in the choice of profession by determining the indicative numbers that is needed to be met when placing young people in individual spheres of the economy. The choice of profession is thus no longer part of the individual's free private choice, but becomes a social obligation. The main mean in the professional orientation of the pupil should be the school and the counseling system serving for the right choice of profession. It is characterized by a sophisticated organization and synergy of services provided, the aim of which is to systematically influence the professional orientation and choice of profession in accordance with the needs of society.

Keywords vocational guidance, period of socialism, vocational education, youth placement, educational counselor, educational counseling system

\section{Počiatky poskytovania poradenských služieb v oblasti vol'by povolania}

Na vývoj pedagogicko-psychologického poradenstva a profesionalizácie poskytovaných služieb v oblasti vol'by povolania v európskom priestore mali zásadný vplyv výskumníci a zakladatelia prvých laboratórií. ${ }^{2}$

1 Príspevok je súčastou riešenia projektu VEGA č. 1/0106/20: Sloboda vs. nesloboda vo vzdelávaní a výchove na Slovensku v období rokov 1948-1989.

2 Pedagogicko-psychologická starostlivosṫ má svoje začiatky v Anglicku, v roku 1884 tu Francis Galton založil tzv. antropometrické laboratórium. 
Tieto spočiatku slúžili predovšetkým na „meranie“ dedičných predpokladov pre vhodný výber zamestnania. Jednalo sa najmä o využívanie psychológie ako vedy priamo v praxi, postupne sa vyvíjali prvé psychologické výchovné kliniky orientované na deti a mládež. ${ }^{3}$ Výchovné poradenstvo významne ovplyvnilo založenie francúzskeho pedagogického laboratória. ${ }^{4}$

Súbežne s nimi sa vyvíjali vtedy označované tzv. „psychotechnické poradne“, v ktorých sa namiesto kazuistických postupov preferovali psychometrické postupy. ${ }^{5}$ Tento prúd ovplyvnil i založenie prvej českej poradne pre vol'bu povolania v roku 1919 pri českom odbore krajskej rady živnostenskej v Brne. O rok neskôr vzniká poradňa i pri zemskej centrále práce v Prahe. V roku 1920 je založené i Ústredie poradní pre vol'bu povolania, ktoré sa pripojilo v roku 1921 k Psychotechnickému ústavu Masarykovej akadémie práce (Kohoutek, 1999, s. 4).

Postupne sa skúmala a profesionalizovala samotná poradenská činnost̉ a výber poradcov. ${ }^{6} \mathrm{~V} 20$. rokoch ústavy sledovali najmä otázky fyziológie a psychológie práce v oblasti priemyslu. Postupne sa ústavy osamostatňujú a diferencujú podla cielovej skupiny napr. pre dospelých, vysokoškolskú mládež, dorast. ${ }^{7}$ I samotné podniky a závody si zriad’ovali vlastné poradne. ${ }^{8} \mathrm{~V}$ 30. rokoch sa vdaka zakladaniu zemských ústredí pre vol'bu povolania začínala otázka výberu profesie riešit

3 V roku 1982 sa z Galtonovej kliniky stáva poradenská klinika orientovaná na deti Child guidance clinic.

4 Založené v Paríži Alfredom Binetom v roku 1905.

5 Poradňa mala svoje kuratórium i sprostredkovatelňu učňovských miest. Psychotechnické oddelenie vybudoval psychológ a pedagóg Otakar Chlup.

6 V roku 1925 vychádza zborník „Správna vol’ba povolania“ (Lancová, Říha, Stejskal, Šeracký), ktorú vydáva Odbor pre zriad’ovanie poradní pre vol'bu povolania Psychotechnického ústavu, v ktorých bližšie špecifikujú požiadavky na osobnost́ poradcov.

7 Poradne orientované pre školopovinnú mládež vznikali pri úradoch pre starostlivost’ o deti a mládež. Pre stredoškolskú a vysokoškolskú mládež vznikajú akademické poradne. Prvá vzniká v roku 1935 v Prahe (zakladatelom bol V. Tardy), v Brne viedol poradňu R. Konečný.

8 Poradňu pre vol’bu povolania zriadila v roku 1937 firma Bata v Zlíne. Využívali ju Vítkovické závody, či Elektrický podnik Praha apod.). 
komplexne. Na základe šetrení tak v hrubých rysoch bolo možné predpokladat hospodárske perspektívy v konkrétnych odboroch. Využívajú sa individuálne ale i skupinové metódy pre zachytenie čo najväčšieho počtu klientov. V tomto období sa preto do procesu meraní na sledovanom území zapájajú i samotní učitelia škôl. ${ }^{9}$

Rozvoj profesionálneho zistovania predpokladov pre výber povolania zásadne ovplyvnilo organizovanie týždenného medzinárodného Psychotechnického zjazdu v roku 1934 v Prahe. ${ }^{10}$ O vtedajšom stave poradenských služieb v Československu informovali psychotechnické ročenky. ${ }^{11}$ Poradne boli viac menej nezávislé na školskom systéme, ich účel mal skôr ekonomicko-informačný a poradenský. Na území Slovenska vznikla v roku 1928 prvá Ústredná poradňa pre vol'bu v Bratislave ako súčasṫ psychotechnického ústavu, poradňu riadil J. Stavěl. ${ }^{12}$ Kohoutek (1999, s. 6) uvádza, že postupne popri ústave na Slovenskom území vzniká 26 okresných poradní pre vol'bu povolania pri „okresnej starostlivosti o mládež“ “ ${ }^{13}$

Medzi hlavné nedostatky poskytovaných služieb poradnív medzivojnovom období možno označit jednostranné merania psychických predpokladov človeka na základe jednorazového šetrenia ${ }^{14}$ a nedostatok

9 Jednalo sa o 14ročnú populáciu dievčat a chlapcov. Porovnávali sa údaje učitelov s „psychogramami“ - záznamoch o psychike a osobnosti klienta, ktoré poradne vypracovávavali. O rozšírenie siete poradní sa zaslúžil ako dorastový referent V. Chmelař, zabezpečoval „supervízne“ služby 70 poradniam na území celej Moravy, ktoré od roku 1931 organizoval.

10 Realizoval sa pod záštitou prezidenta T. G. Masaryka, zúčastnilo sa ho približne 250 účastníkov so 130 referátmi. Pozvanie prijali významné osobnosti poradenstva ako E. Claparede, M. V. Baumgartnerová, Ch. Sperman.

11 V roku 1934 vychádza prvá Psychotechnická ročenka redigovaná J. Doležalom a F. Šerackým, v ktorej sa uvádza, že diagnostiku v celej ČSR podstúpilo 20 tis. detí a dospelých.

12 V poradni pôsobil ako 1. asistent J. Čečetka a psychológ A. Jurovský, ktorý od roku 1938 ústav viedol.

13 Po roku 1945 boli v každom okrese zriadené psychotechniké referáty pri okresných úradoch práce, ktoré metodicky usmerňoval Československý ústav práce s oblastnými ústavmi pre Slovensko v Bratislave a Košiciach.

14 Individuálne vyšetrenie v poradni niekedy trvalo 5-6 hodín, hromadné šetrenia sa realizovali v školách. 
kvalifikovaných psychológov, ktorých zastupovali učitelia inklinujúci $\mathrm{k}$ psychotechnickej činnosti. ${ }^{15}$ Významný prínos pre rozvoj poradenských služieb mal Ústav ludovej práce v Prahe, neskôr premenovaný na Československý ústav práce a oblastný úrad práce s pobočkou v Košiciach, ktoré boli v roku 1951 zrušené a poštátnené. Predvojnový stav ústavov, poradní a referátov pre vol'bu povolania bol na úrovni ostatných vyspelých krajín Európy. Činnost ústavov pre vol'bu povolania prerušila 2 . svetová vojna ${ }^{16}$ a následne nástup nového politického režimu.

\section{Povojnové obdobie v poradenskej činnosti v oblasti vol'by povolania}

Oblast' poradenských služieb na medzinárodnej úrovni po 2. sv. vojne ovplyvnili dva významné dokumenty, a to Odporučenie č. 25 o rozvoji školských psychologických služieb vo výchove z 11. medzinárodnej konferencie UNESCO o výchove z roku 1948, resp. v ktorom sa kladie dôraz na uplatňovanie hladiska psychického vývoja, poskytovanie rád učitel’om a zriad’ovanie špeciálnych odborných služieb a Odporučenie č. 56 o organizácii školského, resp. výchovného a profesionálneho poradenstva z 26. medzinárodnej konferencie v roku 1963, v ktorej sa uvádza objektívna potreba existencie odborných poradenských služieb typu profesionálneho ${ }^{17}$ poradenstva $\mathrm{v}$ odborných službách a funkcia školského poradenstva (Liberčanová, 2017).

V čase ked" sa napr. na Northwesterskej konferencii v USA zavádzali a štandardizovali pojmy poradenskej psychológie v oblasti vol'by povolania, na našom území nastáva v tejto oblasti začiatkom 50. rokov poradenské vákuum. Odborníci, najmä psychológovia, boli považovaní za predstavitel’ov „buržoáznej pavedy“ a neboli už vhodní pre štátne zámery pre oblast’ profesijnej prípravy mládeže, ktorá by viedla

15 Napriek tomu dosahovali poradne vysoké skóre v predvídatelnosti ako sa uchádzač v praxi osvedčí. Chmelař uvádzal až $94 \%$ istotu.

16 České poradne pracovali až do roku 1941.

17 V tomto období sa termínom profesijná výchova, poradenstvo, orientácia (neskôr profesná) označovala profesijná príprava dnes chápaná i v užšom slova zmysle ako kariérová. 
k adekvátnej vol'be budúceho povolania. Nová štátna moc chcela pevne držat’ opraty pri orientovaní mládeže pri vol'be povolania a plánovaní rozmiestňovania pracovných síl. Po 2 . svetovej vojne boli dovtedy poskytované služby poradcov pre vol'bu povolania považované za brániace rozvoju ekonomiky. Psychologické poradenstvo bolo kritizované z ideologických dôvodov. Ako hlavný argument sa uvádzalo tvrdenie, že po porážke vykoristovatel'ských tried vznikne beztriedna spoločnost', v ktorej nebudú existovat problémy vo výchove, s kriminalitou detí a mládeže, s vol'bou povolania a štúdia. Pedagogika bola akoby bez dietatá, teda bez znalosti o jeho psychike, bez psychológie (Kohoutek, 1999, s. 7). Táto argumentácia zamestnaneckej politiky štátu pretrvávajúca až do konca 60. rokov mala priamy dopad na profesijnú výchovu a budúci výber povolania.

Po roku 1948 sa preto v novom školskom zákone počíta s poradenstvom pre vol'bu povolania iba na školách, ktoré sa orientujú len na ekonomicko-náborové kritériá a organizačno-administratívne postupy. Ostatné faktory vstupujúce do profesijného poradenstva boli podceňované. Vzţah medzi spoločenskou, ekonomickou a individuálnou sférou bol podceňovaný. Diferenciácia ludí vzhladom na ich individuálne špecifiká nebola pre nastupujúci totalitný režim žiaduca. Profesia psychológa bola na školách vnímaná ako „trójsky kôň“, dokonca boli označovaní za „černokňažníkov imperializmu“. Rovnaký osud zastihol i poradne pre vol'bu povolania, ktorých existencia a rozvoj bola z rovnakých dôvodov až do konca 50. rokov úplne prerušená. Základným predpokladom pre takto orientovanú školskú politiku predstavovali zákony, v ktorých vláda jasne deklarovala svoje smerovanie $\mathrm{k}$ upevňovaniu vládneho režimu. Po prijatí zákona o základnej úprave jednotného školstva z 21. apríla 1948 a IX. zjazde KSČ konanom v máji r. 1949, sa vytýčila hlavná línia budovania socializmu v oblasti školstva a výchovy v Československu, teda aby sa v školách vychovávali ludia verní a oddaní socializmu v duchu marxizmu-leninizmu. Škola mala byt’ oporou socialistického zriadenia; jej práca musela vychádzat’ z princípu jednoty výchovy a vyučovania a spojenia školy so životom, ktoré boli prijaté na zasadnutí ÚV KSČ v apríli 1959. Následne vládnym 
uznesením z 30. augusta 1961 boli ustanovené zásady pre zabezpečenie práce žiakov a študentov vo výrobe.

\section{Rozmiestňovanie pracovných síl, pracovná výchova a polytechnické vzdelávanie}

Cielom výchovy a poradenstva pre vol'bu povolania v období budovania socializmu bolo zabezpečenie vládnych programov ustanovených na komunistických zjazdoch. Jednalo sa o premyslený systém rozmiestňovania absolventov stredných a vysokých škôl a „usmerňovanie“ žiakov posledných ročníkov základných škôl na základe tzv. smerných čísel, ktorými sa určoval potrebný počet žiakov pre štúdium $\mathrm{v}$ jednotlivých hospodárskych odvetviach. Ideál zvyšovania robotníckej inteligencie sa však vláde nedaril dosahovat’ dlhodobo.

Podla uznesenia zo dňa 23. apríla 1959 „O úzkom spojení školy so životom a d’alšom rozvoji výchovy a vzdelávania v Československu“ sa zaviedli rôzne formy $v z$ delávania popri zamestnaní, ktoré v roku 1965 už navštevovalo vyše 15000 študentov. Mali za ciel umožňovat́ zvyšovat̉ si dodatočne kvalifikáciu. Štát tak chcel zabezpečit̉ možnosť štúdia na vysokých školách i tým robotníkom, ktorí boli bez požadovaného potrebného stupňa vzdelania, a tak zvyšovat’ vzdelanostnú úroveň a celoživotné vzdelávanie pracujúceho ludu. Robotníci mali nastúpit do riadiacich pozícií a nahradit tak pôvodnú inteligenciu.

Pre socialistickú pracovnú výchovu spolu s polytechnickým vzdelávaním a profesijnou orientáciu zohrávala dôležitú funkciu kolektívnosṫ. Na ZDŠ sa pracovná výchova zavádzala postupne od roku 1948 ako verejnoprospešná práca, realizovala sa dobrovolne a mimo vyučovania (pestovatel'ské, chovatel'ské krúžky) (Gubricová, 2018), v septembri 1955 sa dostáva do vyučovania ako ručné práce a praktické cvičenia v dielňach, po roku 1959 s názvom predmetu pracovné vyučovanie. Baláž (1970) uvádza, že v ČSSR sa na ZDŠ rozlišovali štyri druhy fyzickej práce, a to učebné práce (najmä pracovné vyučovanie), verejnoprospešné práce (podla spoločenských a hospodárskych potrieb), záujmové krúžky a produktívne práce (v spolupráci s podnikmi). Zložka sa mala uplatňovat vo všeobecnovzdelávacích predmetoch, polytechnickom vyučovaní, 
pracovnom vyučovaní, nepovinných predmetoch, v mimoškolskej činnosti. 16. apríla 1959 sa v Bratislave uskutočnila prvá polytechnická konferencia, počas ktorej sa kládol dôraz predovšetkým na polytechnizáciu všeobecných predmetov, a to najmä prírodovedných, zvyšovanie kvalifikácie učitelov týchto predmetov a na budovanie názorných kabinetov v technických predmetoch.

Podla Smernice o výchove $k$ vol'be povolania na stredných všeobecnovzdelávacích a stredných odborných školách z roku 1963 tažisko práce spočíva na poradcovi pre výchovu k vol'be povolania. Výchovný poradca-učitel'školy - sa tak v období socializmu stáva základným pilierom novej sústavy výchovného poradenstva. Pre rozmiestňovanie absolventov na školách boli zriadené tzv. rozmiestňovacie komisie a pri ZRPŠ a školských komisiách národných výborov sa utvorili komisie pre výchovné poradenstvo a vol'bu povolania, ktoré sa vyznačovali velmi nízkou pripravenost̉ou na kvalitnú profesionálnu prácu. Začiatkom 70. rokov preto poverili národné výbory a odbory školstva komisie tvorbou a disemináciou informačných sprievodcov, ktorí by rodičom objasňovali potrebu napĺňania smerných čísel.

Špecifickú oblast̉ práce v socialistickej spoločnosti zohrávala ideová pracovná výchova, zabezpečovaná v školách, pracoviskách a v povedomí občanov. Práve pracovná výchova zohráva dominantné postavenie v profesionálnej výchove. Prostredníctvom pracovnej zložky vo výchove sa zabezpečuje požiadavka prepojenia školy so životom, ktorá je stanovená už v prvých školských zákonoch a usmerneniach. Práca sa stáva ústredným prostriedkom robotníckeho ludu, ktorý sa má stat’,vedúcou triedou“v spoločnosti. Práve pracovná výchova mala primät a motivovat žiakov volit si povolania robotníckeho charakteru. V užšom slova zmysle sa pracovná výchova v oblasti vzdelávania označovala ako technické vzdelávanie. $\mathrm{V}$ tomto období sa prepájanie moderných výdobytkov vedy a techniky vo vzdelávaní označuje pojmom polytechnická výchova, jej postupné zavádzanie má zabezpečit progres v oblasti hospodárstva. Neskôr sa na základe Zákona o sústave základných a stredných škôl z 22. marca 1984 kladie dôraz i na polytechnizáciu stredných odborných škôl a gymnázií. 


\section{Vznik poradenského systému pre deti a mládež v období socializmu}

Kým v západnej Európe pokračoval vývoj servisných poradenských poradní pre vol'bu povolania založených na rozvíjaní najnovších vedeckých poznatkov a výskumu, na našom území sa začínajú zriad’ovat detské psychologické kliniky a poradne ako zariadenia národných výborov s určitým oneskorením. Prvá psychologická výchovná klinika vzniká v Bratislave ${ }^{18}$ v roku 1957, neskôr v Brne 1958 a Košiciach v roku 1959. Vznikajú ako reakcie na pretrvávajúce problémy vo vývoji, výchove, vzdelávaní detí, ale i ako potreba poskytovat služby v profesijnom poradenstve. Zriad’ovanie kliník a poradní bolo vždy nejako spoločensky zdôvodňované, aby boli v súlade s aktuálnymi potrebami štátu. Za najvýznamnejšie z hladiska vol'by povolania možno považovat', že pri klinikách vznikajú ako ich organické súčasti strediská pre vol'bu povolania. Od svojho založenia ich predstavitelia úzko spolupracovali s poradenskými psychológmi z katedier českých a slovenských univerzít. ${ }^{19}$

Od roku 1959 sa Kolégium Ministerstva školstva a kultúry v ČSR niekol'kokrát zaoberalo prípravou mládeže pre vol’bu povolania. Na základe uznesenia 21/60 začalo experimentálne s rozvijaním výchovy k povolaniu na 30 vybraných školách. Potvrdilo predpoklady a požiadavku odborníkov na vytvorenie osobitej profesie a rozšírenie výchovných

18 Vzhl’adom na aktuálne spoločenské potreby vzniká s určitým oneskorením 1. februára 1957 Psychologická výchovná klinika na Legionárskej ulici v Bratislave, ktorá bola prvým pracoviskom svojho druhu vo vtedajšom Československu. Kliniky mali byṫ odpoved’ou na spoločenskú objednávku, pretože psychológia so svojimi poznatkami, predovšetkým z vývinovej psychológie, možnostami diagnostiky, optimalizácie, intervencie do osobnostného, sociálneho a študijno-profesionálneho vývinu, prevencie sa javila ako účinný pomocník pri riešení mnohých aktuálnych problémov súvisiacich s deṫmi, mládežou a školou. Na jej založení mal významný podiel Miroslav Bažány. Jej cielom bolo predchádzat', usmerňovat a odstraňovat rôzne poruchy správania, tažkostí v učení a v sociálnom vývine mladého človeka (M. Šefránková, 2007).

19 Dětská psychologická poradna nadviazala na predchádzajúcu tradíciu s učitel’mi, lekármi, psychológmi, výskumníkmi a úzko spolupracovala s Katedrou pedagogiky a psychológie Filozofickej fakulty v Brne, ktorá ju rozvíjala odborne a metodicky (V. Chmelař a B. Bárta). 
zariadení orientujúcich sa na profesijné poradenstvo. ${ }^{20}$ Súčasne bol navrhnutý predbežný plán štúdia výchovných poradcov na univerzitných katedrách psychológie. Významnou osobnostou pri zakladaní samostatného Ústavu psychológie profesionálneho vývinu a poradenstva bol profesor J. Kočšo. ${ }^{21}$ Následne zriadilo ministerstvo školstva v roku 1961 Ústrednú komisiu pre výchovné poradenstvo, prostredníctvom ktorej sa mala venovat’ väčšia pozornosṫ i výchove talentovaných žiakov (politicky atakované podozrievaním z elitárstva) a zaostávajúcich žiakov a mládeže s výchovnými problémami. Výsledkom viacerých rokovaní bolo vydanie zásadných Smerníc o vybudovaní sústavy poradenskej sústavy na ZDŠ (1962) a na stredných školách (1963), v ktorých sa ukladá povinnosṫ zriadit pre 6.-9. ročník na každej škole funkciu výchovného poradcu. V roku 1963 bola táto funkcia zriadená na stredných všeobecnovzdelávacích školách a v 70. a 80. rokoch aj na odborných školách a učilištiach. ${ }^{22}$

Zavedenie smerníc umožnilo zriadit experimentálne postgraduálne štúdium výchovného poradenstva v spolupráci s Pedagogickou fakultou a psychologickým ústavom Univerzity Karlovej v Prahe od akademického roku 1966/67. ${ }^{23}$ Štúdium bolo primárne orientované

20 Evalvácia pokusu bola publikovaná v zborníku z interdisciplinárnej porady v dňoch 10.-11. 4. 1960 v Bratislave.

21 J. Koščo od roku 1957 úzko spolupracoval profesorom J. Doležalom (vtedajším riaditelom Psychologického ústavu Karlovej univerzity) pri zakladaní a riadení činnosti pracovnej skupiny Ministerstva školstva v Prahe a pri vypracovaní základnej koncepcie budovania sústavy výchovného poradenstva (od roku 1959 už ako celoštátnej komisie pre výchovné poradenstvo) (Dianovská, 2014).

22 M. Klímová (1988, s. 5) uvádza, že smernica bola prvým krokom k plneniu jedného zo záverov pridelených školskej správe uznesením XI. zjazdu KSČ a na neho nadväzujúcim uznesením ÚV KSČ z 23. 4. 1959 „O úzkom spojení školy so životom a o d’alšom rozvoji výchovy a vzdelávania v Československu“. Vel'ká pozornoste bola venovaná najmä poradenstvu pre výber povolania, kedže v druhej polovici 50. rokov neukončilo povinnú osemročnú dochádzku priemerne 20 \% žiakov populačného ročníka.

23 V rovnakom čase umožňovala štúdium výchovného poradenstva i Katedra psychológie Filozofickej fakulty v Brne, a to formou postgraduálneho štúdia pre absolventov vysokoškolského učitel'ského štúdia, ale i formou vysokoškolského kurzu pre tých, čo neabsolvovali vysokoškolské štúdium. 
na profesionálnu orientáciu detí a mládeže, o čom svedčilo študijné kurikulum a záverečné práce výchovných poradcov, ktoré bolo z hladiska obsahu na pomerne vysokej odbornej úrovni (Liberčanová, 2017). Nemenej významné bolo i založenie Ústavu psychológie profesionálneho vývinu a poradenstva UKv Bratislave, ktorý metodicky usmerňoval a riadil pracovníkov krajských stredísk pre vol'bu povolania a prostredníctvom nich i prípravu výchovných poradcov na školách I. a II. cyklu. V tom období sa pri ústave začínajú formovat začiatky povojnového výchovného poradenstva pre vysokoškolskú mládež v tzv. akademickej poradni (1968).

Všeobecne bol prijatý názor, že škola je prvým východiskovým a základným článkom profesionálnej orientácie a poradenstva. Smernica MŠ o Krajských psychologických výchovných klinikách a Strediskách pre vol'bu povolania (1967) a Smernica o zriad’ovani okresných poradenských zariadení (1970) sa stali základnými kameňmi budovania poradenského systému nielen na Slovensku, ale i v celej ČSSR. Výchovný poradca zastával v tomto systéme úlohu prvého realizátora a koordinátora poradenských služieb. Práve prvá inštrukcia z 29. marca 1967 MŠ ČSR pod. č. j. 4685/67-1/2 O zriadovaní krajských odborných psychologicky výchovných pracovisk podnietila vznik viacerých nových poradní, napr. v Prahe (Hrabal), pri Pedagogickej fakulte Karlovej Univerzity vzniklo Laboratórium sociálneho výskumu mládeže a výchovného poradenstva (Kaduha, neskôr Klímová), z neho sa postupne vybudoval Ústav sociálneho výskumu mládeže a výchovného poradenstva (Liberčanová, 2017).

\section{Vývoj výchovného poradenstva v období normalizácie a jeho vplyv na vol'bu povolania}

Vol'bou povolania sa v 50. rokoch systematicky zaoberali strediská pre vol'bu povolania pri výchovných psychologických klinikách, ktoré v 60. rokoch experimentálne overovali zavádzanie výchovných poradcov priamo na školách. Príznačné pre poskytovanie poradenstva pre vol'bu povolania $v$ 70. rokoch je prehĺbenie paralelných prístupov na území Česka a Slovenska pri konštituovaní systému výchovného poradenstvo. Systém poradenstva sa na týchto územiach začal vyvíjat’ odlišne už začiatkom 60. rokov. A tak sa po prijatí zákona o československej 
federácií tieto systémy poradenstva formujú oddelene. V Čechách na základe uznesenia vlády ČR č. 27/1972 malo školské poradenstvo vo svojej činnosti využívat vedeckú základňu a služby republikových odborných pracovísk, najmä Ústavu sociálneho výskumu mládeže a výchovného poradenstva pri Pedagogickej fakulte UKv Prahe. Ten pre potreby poradenstva vydával časopis Výchovný poradce (1963). Na Slovensku zostáva metodicko-výskumným pracoviskom usmerňujúci chod psychologických výchovných kliník nad’alej Výskumný ústav detskej psychológie a patopsychológie, ktorý vydával časopis Psychológia a patopsychológia dietata. Z komparácie príspevkoch orientovaných na profesijné poradenstvo publikovaných do roku $1988 \mathrm{v}$ oboch časopisoch možno sledovat́ zásadné rozdiely ako $\mathrm{v}$ ich frekvencii, tak i v celkovom obsahovom zameraní. Odlišnost̉ príspevkov vyplývala z funkcie a úlohy realizátorov profesionálneho poradenstva (psychológovia vs. učitelia), pre ktorých boli články určené. Kým psychológovia z poradní rozvíjali teóriu a výskum v oblasti prípravy na výkon profesie mládeže, učitelia vykonávali administratívno-metodickú činnost̉ determinovanú aktuálnymi potrebami štátnej politiky. ${ }^{24}$

V roku 1976 organizáciu poradenského systému zásadne ovplyvnilo zavedenie Inštrukcie o sústave výchovného poradenstva vodbore pôsobnosti Ministerstva školstva ČSR, na základe ktorého sa stanovuje jednotný systém poradenstva, úplne centralizovaný riadením ministerstva

24 V časopise Výchovný poradca je venovaný profesijnej príprave najväčší podiel príspevkov ( $\Sigma 118)$, z kvalitatívneho hladiska tu nachádzame témy ako Rozmiestňovanie dorastu v roku 1969, Klasifikácia profesií a profesionálneho poradenstva (1972), Výsledky rozmiestnenia dorastu v prvej polovici pätročnice (1974), Niektoré aspekty vol'by povolania v ústavných zariadeniach (1978), Využitie kvalifikačných katalógov robotníckych systémov vo VP (1983), Študijné a profesionálne zámery žiakov gymnázií, SOŠ a SOU vo výskume (1986). V časopise Psychológia a patopsychológia diet́ata sa oblasti profesijného poradenstva venuje ovela menšia pozornosṫ $(\Sigma 21)$, témy sú po kvalitatívnej stránke orientované skôr na predpoklady a celkovú spokojnost́ jedinca so štúdiom, či výberom povolania napr. štúdie Profesionálny vývin a jeho zistovanie pri vol'be povolania (1979), Spokojnosṫ a nespokojnosṫ u študujúcej mládeže (1970), II. československý seminár o poradenstve v školskom a profesionálnom vývine (1973), Psychológia profesionálneho vývinu mládeže (1982), Diagnostika a predikcia v profesionálnom poradenstve (1987) (Liberčanová, 2018. s. 159). 
školstva. Hlavným priestorom pre jeho realizáciou sa stáva výchovno-vzdelávacia sústava. Jednalo sa o zavedenie nového trojstupňového modelu výchovného poradenstva v školstve, ktorý tvorili:

1. výchovný poradca v škole,

2. okresná pedagogicko-psychologická poradňa,

3. krajská pedagogicko-psychologická poradňa. ${ }^{25}$

Vznikli transformáciou dovtedy zriadených psychologických výchovných kliník v jednotlivých okresoch na základe edukatívnej koncepcie poradenstva z dielne M. Klímovej (1970). Vychádzala z reformy francúzskeho systému výchovy vzdelávania (P. Langevin, H. Wallon), s ktorou sa stotožnila a presadzovala Komunistická strana Francúzska. Bola v protiklade $\mathrm{s}$ biodromálnym konceptom poskytovania psychologického poradenstva vychádzajúceho z idey vývinu a vývinových úloh svetových predstavitelov (Levitov, Vygotskij, Rubinštejn, Wallon, Piaget, Super, Stavěl, Příhoda), ktorú preferovali slovenskí navrhovatelia jednotného systému poradenstva (J. Koščo, O. Blaškovič, J. Hvozdík, M. Bažány, B. Bárta a iní).

Odborníci z radu psychológov kritizovali Inštrukciu nielen pre samotnú zmenu názvov psychologických výchovných poradní na pedagogicko-psychologické, ktoré podla nich jasne deklarovali, že do popredia sa dostávajú iné štátne priority, teda presadzovanie pedagógov vo výchovnom poradenstve. Upozorňovali na nepriaznivé zmeny i v poradenstve pre výber povolania. Napriek tomu, že poradne vo svojej činnosti uplatňovali moderné poradenské prístupy a odborníci odvádzali činnost́ na profesionálnej úrovni porovnatelnú s vyspelými krajinami, činnosť oddelení bola kontrolovaná komisiami pre vol’bu povolania

25 Podrobnejšie rozpracovaný obsah a systém poradenstva bol obsahom Vyhlášky č. 99 z mája 1980 MŠ SSR o výchovnom poradenstve. Poradenský systém druhého a tretieho stupňa zabezpečovali odborníci na profesionálnej úrovni. Bol však nedostatočne saturovaný potrebným počtom zamestnancov. Metodici profesionálneho vývinu poskytovali podporu výchovným poradcom na školách. Realizovali napr. výcviky v metódach poznávania žiakov a pod. Pre profesijné poradenstvo boli v poradniach vytvorené oddelenia profesiálneho vývinu. 
pri okresných národných výboroch. So zmenou názvu sa do poradní začali dosadzovat často nevzdelaní metodici z výborov, ktorí mali za úlohu „usmerňovat“ činnosṫ odborníkov v poradniach. ${ }^{26}$ Zásahy zo strany politicky nominovaných „odborníkov“ tak mali zabezpečit, aby poskytované služby zodpovedali potrebám socialistickej spoločnosti. Podielali sa na tvorbe metodických usmernení, prostredníctvom ktorých prebiehala depistážna, diagnostická a poradenská činnost̉ pri vol'be povolania. Diagnostikovanie záujmov a predpokladov jedinca v pedagogicko-psychologickej poradni bolo následné „optimalizované" na základe aktuálnych politicko-hospodárskych potrieb. Poradenské služby pre vol’bu povolania mali pôsobit’ na „rozširovanie“ záujmov jednotlivca vzhl'adom na spoločenskú objednávku štátu (Obr. 1).

Poradenské služby pre vysokoškolskú mládež začala poskytovat’ i Akademická poradňa pri UK v Bratislave založená v roku 1968, ktorá úzko spolupracovala s Ústavom psychológie a profesionálneho vývinu a poradenstva, v normalizačnom období začleneného do Psychologického ústavu Filozofickej fakulty Univerzity Komenského. ${ }^{27}$ Pracovníci poradne poskytovali psychologické poradenstvo v oblasti profesijné poradenstvo (Hargašová, 1975) najmä študentom, ktorí sa museli

26 Riaditel' výskumného ústavu psychológie a patopsychológie v súhrnnej správe o stave profesijnej orientácie v poradenských zariadeniach SSR, žiada od okresného národného výboru, „že je potrebné nájsṫ primeranú mieru, aby súhrnne poskytovali pomoc, a nie že by zdržiavali v práci resp. boli prítažou. Z toho vyplýva požiadavka na odbornú a osobnú úroveň pracovníkov metodického oddelenia. Ukazuje sa nevyhnutné, aby sa do metodickej činnosti zapájali skúsení pracovníci ostatných oddelení poradne" (Adamovič, 1983, s. 140).

27 Pre výchovné poradenstvo malo vel'ký význam založenie Katedry pedagogickej a psychológie soddelením školskej psychológie vedúcim katedry L. Ďuričom, ktorý spoločne s profesorom J. Hvozdíkom vynaložil enormné úsilie najmä pri experimentálnom overovaním funkcie školského psychológa v podmienkach škôl. Samotné zavedenie školských psychológov však už nenastalo, lebo do platnosti vstúpila inštrukcia z 2. apríla 1976 o sústave výchovného poradenstva v pôsobnosti Ministerstva školstva ČSR (č. j. 8172/76-201), ktorá vo výchovnom poradenstve znamenala presadenie namiesto psychológov do škôl pedagógov. Po tejto inštrukcii až po pád komunizmu sa už školskí psychológovia na školách nemohli uplatnit, napriek tomu, že s určitou nádejou pokračovala ich príprava nadalej v dvojodborovom štúdiu na katedrách psychológie. 
vyrovnávat’ s tým, že nemohli študovat študijné odbory, na základe slobodnej vol'by, ale podla dostupných možností, teda požiadaviek štátu a smerných čísel (Hargašová, 2019) alebo im v štúdiu bránilo rozhodnutie komisie odvolávajúce sa na „nevyhovujúci rodinný pôvod“.

V roku 1979 bola vytvorená Komisia vlády Slovenskej socialistickej republiky pre výchovné poradenstvo. Poradcovia s ňou nespolupracovali, lebo ju chápali ako politický nástroj kontroly štátu, v praxi nebola akceptovaná, a tak v zásade neovplyvnila vývin poradenstva.

Obr. 1. Proces „optimalizovania“výberu povolania jednotlivcom (Lepeňová, 1982, s. 35-36).

SCHÉMA OPTIMÁLNEHO PROFESIONÁLNEHO UPLATNENIA JEDNOTLIVCA $\checkmark$ ŠTRUKTÚRE POVOLANÍ

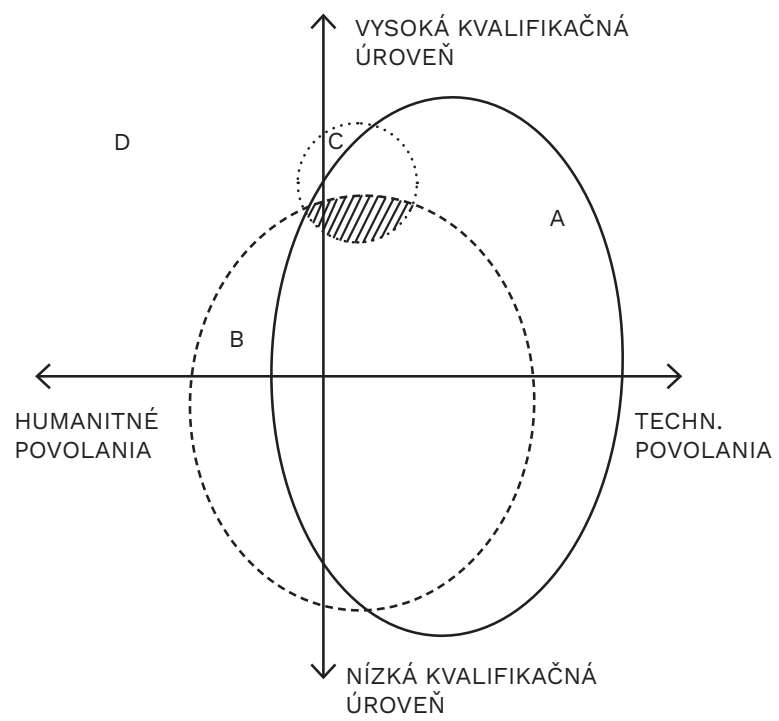

\section{LEGENDA}
A — množina spoločensky preferovaných povolaní
B -..-.-. množina povolaní zodpovedajúcích schopnostiam jednotlivca
C množina povolaní vyhovujúcích vzhl'adom na profesionalne záujmy jednotlivca
D množina všetkých povolaní optimálne profesionálne uplatnenie jednotlivca 


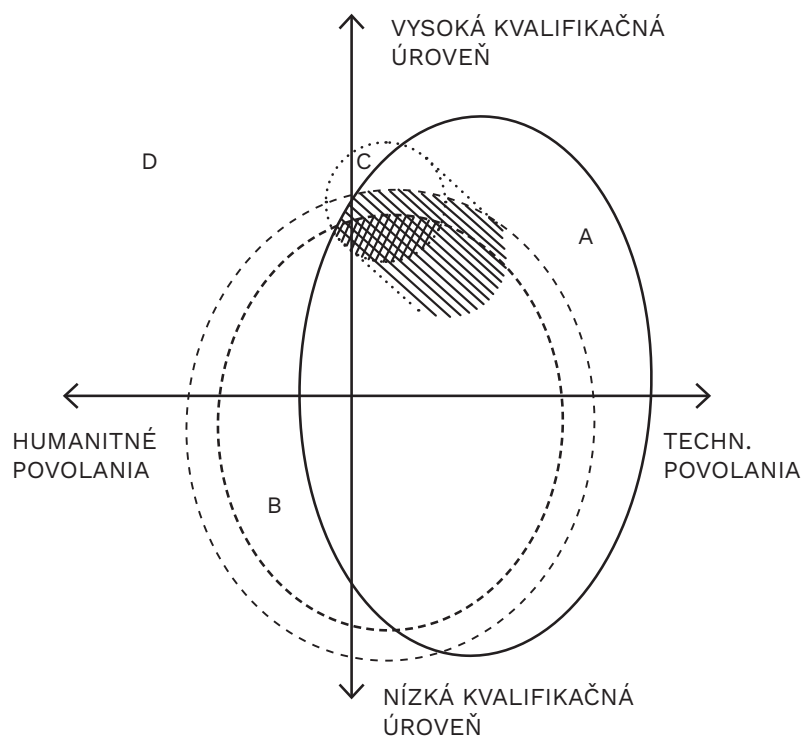

LEGENDA (doplnění legendy z obr. č. 2

- - - - _ - rozšírenie množstva vyhovujúcich povolaní vzhl'adom na indiv. schopnosti

rozšírenie profesionálnych záujmov jednotlivca

DIZZZ rozšírenie možnosti profesionálneho uplatnenia jedinca vzhl'adom na spoločenskú potrebu

\section{Profesionálna orientácia vo výchovnom poradenstve.}

\section{Funkcia výchovného poradcu}

Správna vol'ba povolania a d’alšieho študijného smerovania mala byṫ výsledkom dlhodobej profesionálnej výchovy (Obr. 2) začlenenej do širšieho komplexu výchovno-vzdelávacích komponentov, v ktorej dominantné postavenie zohrávala pracovná výchova a polytechnické vzdelávanie (Boroš, 1978). Stala sa prioritnou súčastou systému výchovného 
poradenstva, v ktorej škola a výchovný poradca zohrávali ústredné postavenie. $^{28}$

Obr. 2. Miesto profesionálnej orientácie vo výchove a vzdelávaní (Hrebíček, 1987, s. 47).

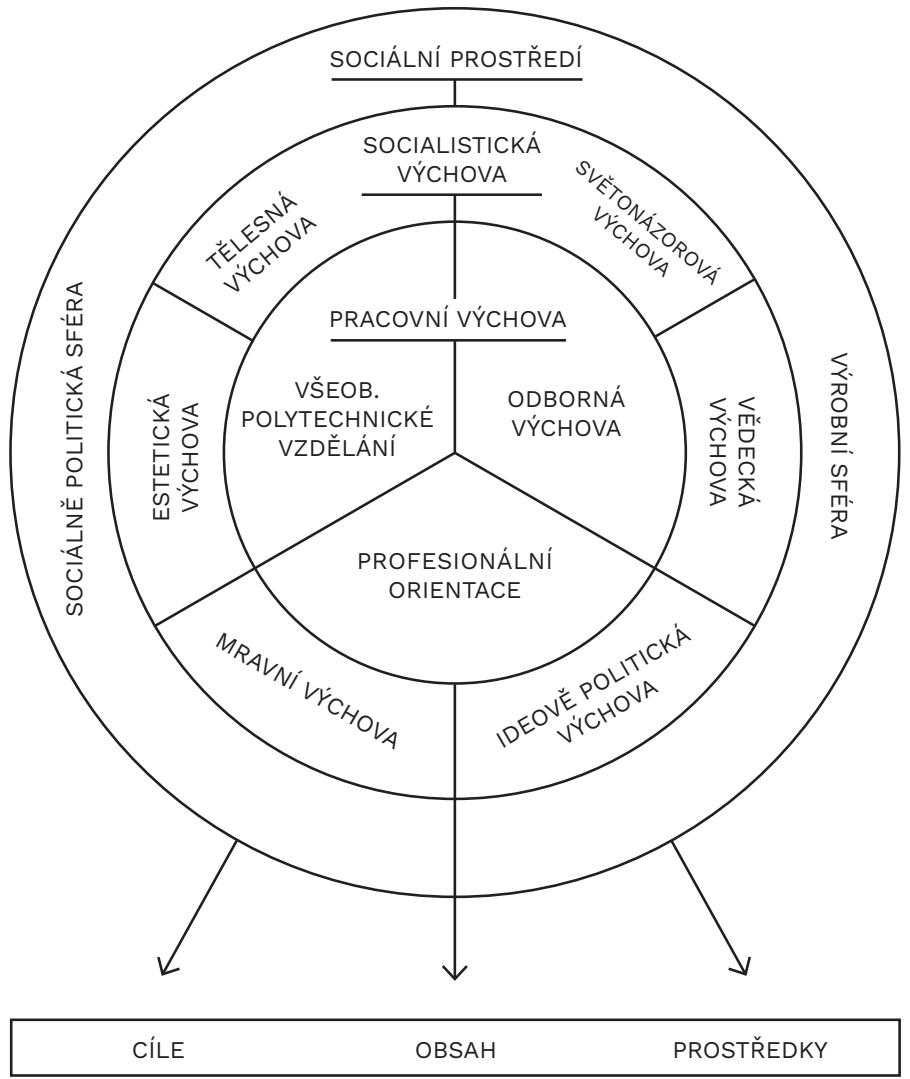

28 Experimentálne sa v bratislavských všeobecnovzdelávacích školách overoval navrhnutý osobitný program výchovy na vol'bu povolania (Fliegel, 1969). Skladal sa z predbežného cyklu od 6. ročníka až po 9. ročník. Jednalo sa o podrobne rozpracované metodiky, ktorých zámerom bolo okrem iného i snaha infiltrovat profesionálnu výchovu naprieč celou výučbou, predovšetkým prírodovedných predmetov, v ktorých bolo potrebné zvýšit záujem žiakov. 
Na poverených učitelov na pozícii výchovných poradcov sa ešte v 60. rokoch preto začali klást̉ pomerne vysoké odborné a politické kritériá. Požadovalo sa od nich absolvovanie dvojročného postgraduálneho štúdia. V štúdiu bola najväčšia pozornosť venovaná práve profesionálnej orientácii žiakov (Liberčanová, 2019), ktorá sa často nesprávne stotožňovala s celkovými úlohami výchovného poradenstva. Medzi hlavné úlohy výchovných poradcov patrilo orientovanie žiakov na robotnícke povolania. Výchovní poradcovia boli na školách zároveň poverení zakladat kabinety školských a profesionálnych informácií (Liberčanová, 2019). Výchovní poradcovia sa riadili Metodickými pokynmi na d’alšie prehĺbenie profesionálnej orientácie a výchovy $k$ vol'be povolania na základných a stredných školách (1977), neskôr inovované ako Metodické pokyny na zvýšenie účinnosti výchovy $k$ vol'be povolania a profesionálnej orientácie žiakov základných a stredných škôl (1982), v ktorých sú uvedené velmi podrobné funkcie učitel'ov výchovných porad$\mathrm{cov}^{29} \mathrm{~V} 80$. rokoch bol už systém profesionálnej výchovy detailne rozpracovaný, aby slúžil na systematické sledovanie, hodnotenie vývinu žiakov a dlhodobú profesijnú orientáciu žiakov zodpovedajúcu ich záujmom a zároveň korešpondujúcu s potrebami socialistickej spoločnosti. Vo výkone profesie sa opieral o Vyhlášku č. 99 z mája 1980 MŠ SSR o výchovnom poradenstve. Výchovný poradca na škole mal za úlohu aj v oblasti vol'by povolania spolupracovat' s príslušnou pedagogicko-psychologickou poradňou, s výkonnými orgánmi národných výborov, so strednými alebo vysokými školami, socialistickými organizáciami pri oboznamovaní žiakov a ich zákonných zástupcov, so školským alebo dorastovým lekárom, prípadne s posudkovým lekárom sociálneho zabezpečenia, so združením rodičov a priatelov školy, s Pionierskou organizáciou socialistického zväzu mládeže alebo Socialistickým zväzom mládeže na škole (Gubricová, 2019). Okrem iných úloh už mal

29 Podla prieskumu (Sádecký, 1985, s. 54) zameraného na zloženie výchovných poradcov z roku 1979/80, vykonávalo funkciu výchovného poradcu 209 žien z celkového počtu 382 skúmaných poradcov, len 21,48 \% má ukončené postgraduálne vzdelanie, 64,13\% absolvovalo základný kurz pre výkon funkcie, 14,39 \% neabsolvovalo žiadnu prípravu. 
poradca venovat pozornost’ aj žiakom zo sociálne znevýhodneného prostredia, žiakom nadaným, talentovaným a žiakom so zmenenou pracovnou schopnostou. Detom a mladistvým s postihnutím mala byt zabezpečená príprava na pracovné uplatnenie alebo zácvik na vykonávanie primeranej práce $\mathrm{v}$ ústavoch sociálnej starostlivosti alebo v zariadeniach denného alebo týždenného pobytu (Šuhajdová, 2018, 2019). Výchova, príprava na budúce povolanie a začlenenie sa do spoločnosti tažko vychovatelných detí a mládeže bola v kompetencii výchovných ústavov (Šuhajdová, 2019).

\section{Orientácia na robotnícke povolania a napíňanie smerných čísel} Ďalším špecifickým fenoménom v oblasti vol'by povolania počas éry socializmu bola tzv. pozitívna diskriminácia žiakov z robotnícke prostredia, ktorej cielom bolo umelé vytváranie tzv. nastupujúcej robotníckej inteligencie z radov detí, ktoré pochádzali z rodín robotníkov. V smerniciach o prijímacom pokračovaní na stredné a vysoké školy sa prihliadalo na triedny pôvod uchádzačov a v istej miere sa uprednostňovali žiaci robotníckeho a rolníckeho pôvodu (Baláž, 1975). Napriek systematickému vplyvu zložiek výchovného poradenstva na žiakov sa ani v 80. rokoch nedarilo dostatočne orientovat žiakov na robotnícke povolania. ${ }^{30}$ Hlavný dôvod autori prisudzovali nedostatočnej motivácii, zlyhaniu pred prvou smerovou vol'bou, a to i napriek tomu, že socialistická výchova prostredníctvom profesionálnej výchovy vyvijala vel'ké úsilie pre zvyšovanie záujmu u žiakov o robotnícke povolania. V skutočnosti však v 80. rokoch boli robotnícke povolania pre študentov nedostatočne atraktívne. Za zvlášt náročné považovali výchovní poradcovia napíňanie stanovených smerných čísel v nepopulárnych alebo nebezpečných povolaniach, akými boli baníci, vojaci, a ovplyvňovanie rodičov

30 Napriek tomu, že každoročné súhrnné správy o rozmiestňovaní pätnástročných uvádzali, že plán rozmiestňovania sa plní na viac ako $100 \%$, skutočnost̉ bola taká, že až pätina mladých kvalifikovaných robotníkov nepracuje v povolaniach, ktoré sa vyučilo a 40 \% tých, ktorí sa vyučili v strojárstve, odchádza pracovat̉ do iného odboru (Sádecký, 1985). 
detí pri výbere týchto povolani. ${ }^{31}$ Vplyv rodičov prirodzene zostáva pri výbere d’alšieho štúdia a povolania nad’alej dominantný. Taktiež náročné a taažko realizovatelné bolo smerovat vol'bu povolania dievčat do oblastí tzv. mužských fyzicky náročných povolaní (bagristka, žeriavnička, traktoristka). Vláda v socialistickom zriadení tak navonok propagovala zrovnoprávnenie nielen spoločenských stavov, ale i pohlaví. Skutočným dôvodom zapájania dievčat bola potreba napĺňania smerných čísel v robotníckych povolaniach. ${ }^{32}$ Osobitne štatisticky sledovanú skupinu v príprave na povolanie predstavovalo rozmiestňovanie tzv. 14 a 15ročného „cigánskeho dorastu“, pretože v tejto oblasti sa nedarilo splňat požadované smerné čísla. ${ }^{33}$ Títo žiaci, najmä dievčatá, boli v osobitej starostlivosti národných výborov.

31 Výchovní poradcovia $\mathrm{z}$ radov učitelov museli realizovat návštevy v rodinách na odlahlých lazoch, či kopaniciach a presviedčat k výberu týchto povolaní, čo bolo pomerne vyčerpávajúce (Cambelová, 2020).

32 Podla celoplošného výskumu zameraného na študijné a profesionálne záujmy žiakov gymnázií a vybraných SOŠ a SOU (Klímová, 1986) sa za najúčinnejšiu formu považovala práve záujmová činnosṫ $(62,4 \%)$, besedy na pionierskych schôdzach (9,92\%), exkurzie na pracoviská (5,67\%) a i napr. sútaž „Čo vieš o robotníckych povolaniach“ (5,57\%). Ako d’alší dôvod neúspechu sa uvádza nedostatočná príprava učitelov na pedagogických fakultách, prípadne chýbajúce postgraduálne štúdium výchovných poradcov. Až 55,73 \% rodičov žiakov, ktorí sa výskumu zúčastnili, pracovalo v robotníckom povolaní. Potvrdilo sa i to, že stále najsilnejší vplyv pri vol'be povolania je na strane rodičov (38\%). Za najúčinnejšiu formu pri výbere povolania boli považované žiakmi exkurzie do závodov (31,18 \%). Vplyv výchovných poradcov a učitelov dosahoval $14,15 \%$.

33 O aktuálnom stave pravidelne informoval Výchovný poradce. V roku $1982 \mathrm{z}$ nich priemerne ukončilo školskú dochádzku v 9. ročníku len $27,5 \%$, kým u všetkej mládeže bola úspešnost' 87,8 \% Až polovica týchto žiakov končila školskú dochádzku v nižších ročníkoch. V priemere dve tretiny z absolventov začali navštevovat učebné odbory, približne štvrtina sa zamestnala a šestina zostáva tzv. nezaradená, a to najmä z dôvodu zdravotných a sociálnych. Špecifickú skupinu predstavujú dievčatá „cigánskeho pôvodu“, ktoré odmietajú nastúpit do učebných odborov. Len 42 \% pokračuje v štúdiu a dve tretiny nastupuje na pracovné miesta. Často sa jednalo o tlak zo strany rodiny, ktorá vyžadovala, aby boli dievčatá čo najskôr zárobkovo činné, a tak sa nepodiel’ali na zvyšovaní kvalifikovanej robotníckej sily (Straková, 1983). 


\section{Záverom $k$ vol’be povolania a vývoja profesijného poradenstva počas obdobia socializmu}

Proces vol'by povolania a jeho profesionalizácia prostredníctvom poskytovania poradenských služieb je determinovaný celkovým vývojom spoločnosti, v ktorej sa uskutočňuje. Stav poradenstva na našom území pred 2. sv. vojnou bol na úrovni vyspelých krajín sveta. Zmena nastala až nástupom novej štátnej politiky po roku 1948, ktorej ciele nekorešpondovali s najnovšími poznatkami a výskumom v profesijnej oblasti. Prirodzený vývoj poradenského systému, ktorý mohol nadviazat̉ na dovtedajšie skúsenosti a tradíciu vo vol'be povolania, bol preto zastavený. Politicko-hospodárska stratégia vlády v období 50. rokov neumožnila potrebnú intervenciu zo strany odborníkov najmä psychológov. Poradenská sústava na našom území je v skúmanom období výrazne determinovaná celkovým vývojom spoločensko-politickej situácie. Poradenstvo pre vol'bu povolania nadväzujúce na experimentálne psychologické poradenstvo, čakalo na opätovné rehabilitovanie psychologických disciplín, ktoré tvorilo dominantnú vedecko-výskumnú bázu v poradenstve orientovanom na deti a mládež. Až pozvolný rozvoj výskumu a obnovenie psychologických výchovných kliník so strediskami pre vol'bu povolania počiatkom 60. rokov umožnil ich návrat. Poradenským odborníkom v tomto období však nie je umožnený vstup do škôl. Funkciu poradcu tu preberajú nepripravení učitelia. Paralelne sa tvorí prostredníctvom pomerne laického zásahu štátu do oblasti profesijného poradenstva nový fenomén výchovný poradca, ktorý má zabezpečit správne smerovanie volieb žiakov a študentov pri výbere povolania. Poradenstvo pre vol'bu sa stáva súčastou výchovno-vzdelávacej sústavy, preniká do výučby jednotlivých predmetov, s orientáciou na pracovnú zložku a celkovú polytechnizáciu vzdelávania. Situáciu výrazne okliešti štátna politika v 70. rokoch konštituovaním novej sústavy poradenstva, s jasne deklarovanou orientáciou na tzv. edukatívnu koncepciu. Socialistická výchova využíva školu ako hlavný prostriedok pre profesionálne poradenstvo, ktoré sa intenzívnejšie rozvija počiatkom 80 . rokoch. Učitelia na pozícii výchovných poradcoch majú plnit funkciu na základe politických potrieb štátu, teda smerných čísel určujúcich potrebné počty uchádzačovv jednotlivých odvetviach 
povolaní. Paralelne s poradenstvom na školách sa rozvíja poradenský prúd v pedagogicko-psychologických poradniach $\mathrm{v}$ oddeleniach profesionálneho poradenstva, v ktorých poskytujú profesionálne služby odborníci na pomerne vysokej úrovni. Ich úlohou je spolupracovat’ s výchovnými poradcami a vytvárat tak trojstupňový model poradenstva. Ich práca býva znevažovaná „optimalizáciou“ zo strany štátnych úradníkov, kontrolórov na pozícii metodikov. Tieto nedemokratické postupy výrazne retardovali vývoj poradenstva v oblasti profesijnej prípravy a vol'by budúceho povolania. Situácia pred pádom politického systému v poradenstve sa vyznačuje neutíchajúcou potrebou otvárat’ a intenzívne rozvíjat’ ostatné, často popierané, či zanedbané oblasti v profesijnej príprave pre mládež so špecifickými potrebami (napr. poradenstvo pre mládež s nadaním, postihnutím, či z marginalizovaných oblastí).

\section{Literatúra}

BALÁŽ, Ondrej, 1975. Učitel’ a spoločnosṫ. Bratislava: SPN. $189 \mathrm{~s}$.

BOROŠ, Július a kol., 1978. Výchovné poradenstvo. Bratislava: SPN. 272 s.

DIANOVSKÁ, Alžbeta a kol., 2014. Výchovný poradca ako súčast̉ poradenského systému - od vzniku po súčasnost'. In: Metodický sprievodca pre poradcu. 222 s. [online]. [cit. 2017-08-06]. Dostupné na: https://www.komposyt.sk/pre-odbornikov/ziak-so-svvp/preview-file/pomoc-v-praxi-register-metodicky-sprievodca-vychovneho-poradcu-1003.pdf.

FLIEGEL, Ladislav, 1969. Osobitý program výchovy na vol'bu povolania. In: Výchovný poradce. Praha: ÚSVMAVP. Roč. VI, č. 1, s. 29-34.

GUBRICOVÁ, Janette, 2018. Presahy ideológie komunizmu do činností detí vo volnom čase v rokoch 1969-1989. In: KUDLÁČOVÁ, Blanka. Pedagogické myslenie a školstvo na Slovensku od obdobia normalizácie po pád komunizmu. Trnava: Typi, s. 166-177. ISBN 978-80-568-0123-9.

GUBRICOVÁ, Janette, 2019. Neformálna edukácia v povojnovom období a v období socializmu. In: KUDLÁČOVÁ, Blanka. Pedagogické myslenie, školstvo a vzdelávanie na Slovensku v rokoch 1945-1989. Trnava: Typi, s. 356-385.

ISBN 978-80-568-0369-1. 
HARGAŠOVÁ, Marta, 1975. Uplatnenie psychologického poradenstva v komplexnom systéme starostlivosti o prijatých poslucháčov. Záverečná správa z riešenia čiastkovej témy výskumnej úlohy. Bratislava: FF UK. Fragmentálna kópia dokumentu.

HREBÍČEK, Ladislav, 1987. Výchova a profesionální orientace. Praha: SPN.

KLÍMOVÁ, Marta, KLÍMOVÁ, Marie \& OPEKAROVÁ-KOVAŘíKOVÁ, O., 1986. Studijný a profesionální zámery žáků gymnázií, vybraných středných odborných škôl a stredných odborných učilišt ve světle výzkumu. 1. část'. In: Vychovný poradce. Praha: ÚVÚMaVP. Roč. XXIII/1986. s. 51-54.

KLÍMOVÁ, Marie, 1988. Aktuální otázky výchovného poradenství. Praha: ÚIŠ. $73 \mathrm{~s}$.

KOHOUTEK, Rudolf, 1999. Historie pedagogicko-psychologického poradenství. Brno: CERM, 24 s. ISBN 80-7204-115-0.

KOŠČO, Jozef. 1971. Psychologické poradenstvo v školstve a profesionálnom vývine. Bratislava: SPN. 296 s.

LEPEŇOVÁ, Darina, 1982. Systém profesionálnych informácií a ich funkcie. In: Výchovný poradce. Praha: ÚSVMAVP. Roč. XIX, č. 3, s. 29-37.

LIBERČANOVÁ, Kristína, 2017. Koncepcie výchovného poradenstva v školskom systéme na Slovensku v rokoch 1945-1968. In: KUDLÁČOVÁ, Blanka (ed.). Pedagogické myslenie a školstvo na Slovensku od konca 2. svetovej vojny po obdobie normalizácie. Trnava: Typi Universitatis Tyrnaviensis, s. 143-152. ISBN 978-80-568-0062-1.

LIBERČANOVÁ, Kristína, 2018. Výchovné poradenstvo v školskom systéme v období normalizácie. In: KUDLÁČOVÁ, Blanka. Pedagogické myslenie a školstvo na Slovensku od obdobia normalizácie po pád komunizmu. Trnava: Typi, s. 152-163. ISBN 978-80-568-0123-9.

LIBERČANOVÁ, Kristína, 2019. Systém výchovného poradenstva. In: KUDLÁČOVÁ, Blanka. Pedagogické myslenie, školstvo a vzdelávanie na Slovensku v rokoch 1945-1989. Trnava: Typi, s. 335-351. ISBN 978-80-568-0369-1.

SÁDECKÝ, Gejza, 1985. Orientácia žiakov na robonícke povolania.Bratislava: SPN. $85 \mathrm{~s}$.

STRAKOVÁ, Anna, 1983. Rozmiestňovanie 14 a 15ročného cigánskeho dorastu na prípravu pre povolanie na Slovensku v roku 1982. In: Výchovný poradce. Praha: ÚSVMAVP. Roč. XX, s. 37-40.

ŠEFRÁNKOVÁ, Mária, 2007. Výchovný poradca. Bratislava: IRIS. 107 s. ISBN 8089256051.

ŠUHAJDOVÁ, Ivana, 2018. Sociálna starostlivosṫ a sociálno-právna ochrana detí a mladistvých v legislatívnom ukotvení po roku 1968. In: KUDLÁČOVÁ, Blanka. Pedagogické myslenie a školstvo na Slovensku od obdobia normalizácie po pád komunizmu. Trnava: Typi, s. 197-202. ISBN 978-80-568-0123-9. 
ŠUHAJDOVÁ, Ivana, 2019. Sociálna starostlivost̉ o deti, mládež a rodinu. In: KUDLÁČOVÁ, Blanka. Pedagogické myslenie, školstvo a vzdelávanie na Slovensku $v$ rokoch 1945-1989. Trnava: Typi, s. 399-421. ISBN 978-80-568-0369-1.

\section{Legislatívne pramene}

Inštrukcia z 2. apríla 1976 o sústave výchovného poradenstva v pôsobnosti Ministerstva školstva ČSR. Č. j. 8172/76-201.

Smernica o výchove $\mathrm{k}$ vol'be povolania na stredných všeobecnovzdelávacích a stredných odborných školách č. 18 711/63-II/5. Z dňa 20. mája 1963. In: Vestnik MŠK, 1963. Zošit 17, s. 190.

Smernica o výchove $k$ vol'be povolania na stredných všeobecnovzdelávacích a stredných odborných školách. In: Věstník MŠK, 1963. Zošit 19, s. 190.

Vyhláška Ministerstva školstva č. 49/67 Zb. In: Smernica MŠ SSR o postgraduálnom štúdiu č. 8043/71 zo dña 1. júna 1971.

Vyhláška Ministerstva školstva Slovenskej socialistickej republiky z 12. mája 1980 o výchovnom poradenstve.

Vyhláška Ministerstva školstva SSR z 12. mája 1980 o výchovnom poradenstve.

\section{Archívne pramene}

ADAMOVIČ, Karol, 1983. Analýza súčasného stavu, foriem a obsahu profesionálnej orientácie $v$ poradenských zariadeniach SSR. Záverečná správa z rezortnej úlohy MŠ SSR. Bratislava: Výskumný ústav detskej psychológie a patopsychológie. $161 \mathrm{~s}$.

HARGAŠOVÁ, Marta, 1989. Prax psychologickej poradne pre vysokoškolákov. Záverečná správa z riešenia výskumnej úlohy RŠ V-05-5 Koncepcia a prax biodromálneho poradenstva pre vysokoškolákov. Bratislava: FF UK, bez číslovania.

\section{Narácie}

CAMBELOVÁ, Anna, 2020. Výchovné poradenstvo v okrese Senica nad Myjavou v období 1953-1988. Rozhovor, máj 2020.

HARGAČOVÁ, Marta, 2019. Psychologické poradenstvo v oblasti profesijného vývinu v akademickej poradni pri UKv období komunizmu. Rozhovor realizovaný v júni 2019. 